\title{
Distribution and concentration of cyclosporin in human blood
}

\author{
KERRY ATKINSON, KATHRYN BRITTON, JAMES BIGGS \\ From the Department of Haematology, St Vincent's Hospital, Sydney, New South Wales 2010, Australia
}

SUMMARY In patients receiving cyclosporin to minimise graft versus host disease after allogeneic bone marrow transplantation, whole blood cyclosporin concentration was roughly twice the serum concentration when blood was separated at $37^{\circ} \mathrm{C}$. In turn, blood separation at $37^{\circ} \mathrm{C}$ resulted in a doubling of serum cyclosporin concentration compared with separation at room temperature. In vitro studies showed that the latter phenomenon was due to a temperature dependent partitioning of cyclosporin between plasma and red cells, such that increased cyclosporin was taken up from the serum into red cells at room temperature. Increasing delay in separation of patient blood (at either temperature) resulted in a gradually increasing cyclosporin serum concentration. Further in vitro studies showed that a distribution equilibrium between blood components was reached within $30 \mathrm{~min}$ incubation. Red cell uptake of cyclosporin was saturable at an incubation concentration of $>4 \mu \mathrm{g} / \mathrm{ml}$, while plasma and mononuclear cells showed a linear uptake to $7 \mu \mathrm{g} / \mathrm{ml}$. The cellular cyclosporin content of a mononuclear cell was roughly 1000 times greater than that of an erythrocyte. For clinical monitoring we recommend the measurement of cyclosporin concentration either in whole blood or in serum separated at $37^{\circ} \mathrm{C}$ without delay after venepuncture.

Cyclosporin, with its unique ability to inhibit $\mathrm{T}$ cell activity, ${ }^{2}$ has become an important drug in human organ transplantation. It is effective in reducing the incidence of solid organ graft rejection ${ }^{34}$ as well as bone marrow graft rejection. ${ }^{5}$ It is as effective as methotrexate in minimising acute graft versus host disease after marrow transplantation. ${ }^{6}$ Unfortunately, it is associated with nephrotoxicity, ${ }^{7-9}$ hepatotoxicity, ${ }^{1011}$ and central nervous system toxicity. ${ }^{12}$ Despite much effort aimed at measuring drug concentrations in serum and whole blood, relatively little information is available on either toxic or therapeutic concentrations. We report on the concentration and distribution of the drug in whole blood and blood components in man and on a number of factors that influence the concentration of cyclosporin in these components.

\section{Material and methods}

PATIENTS STUDIED

All patients were receiving cyclosporin immunosuppression to minimise graft versus host disease after allogeneic bone marrow transplantation as treat-

Accepted for publication 28 June 1984 ment for severe aplastic anaemia or haematological malignancy. The protocol for marrow transplantation has been described previously. ${ }^{13}$ Blood samples were collected from patients receiving cyclosporin immediately before a regular 12 hourly dose of cyclosporin (trough concentration).

For measurement of cyclosporin serum concentration blood was allowed to clot at either room temperature or $37^{\circ} \mathrm{C}$. The clotted blood was centrifuged at $1000 \mathrm{~g}$ for $10 \mathrm{~min}$ at the respective temperatures. All serum samples were stored at $-20^{\circ} \mathrm{C}$ before radioimmunoassay. ${ }^{14}$ In our laboratory the interassay variation was $8.4 \%$ and the intra-assay variation $5.6 \% .^{15}$ To evaluate the effect of the temperature at which the blood was separated on subsequent cyclosporin serum concentration, aliquots of clotted blood were allowed to stand for $1 \mathrm{~h}$ at room temperature or $37^{\circ} \mathrm{C}$ before separation. To investigate the effect of delayed blood separation, aliquots of clotted blood were allowed to stand at room temperature or $37^{\circ} \mathrm{C}$ for $1,4,7$, or $22 \mathrm{~h}$ intervals before separation. For measurement of whole blood cyclosporin concentration, EDTA blood was collected and stored frozen at $-20^{\circ} \mathrm{C}$ until assayed. On the day of assay the sample was thawed, brought to room temperature, and mixed thoroughly. No intact 
red cells were detectable by light microscopy after this procedure. Cyclosporin concentration was then measured by radioimmunoassay. ${ }^{14}$ Again, this was standardised such that a cyclosporin concentration as low as $30 \mathrm{ng} / \mathrm{ml}$ could be measured. The interassay variation was $8.9 \%$ and the intra-assay variation $5.8 \%$.

\section{IN VITRO STUDIES}

Cyclosporin pure substance was dissolved in ethanol and Tween 80 and diluted with $0.9 \%$ sodiur.. chloride solution to give concentrations in the range $0.625 \mu \mathrm{g} / \mathrm{ml}$ to $8 \mu \mathrm{g} / \mathrm{ml}$. Fresh blood (anticoagulated with EDTA) from normal individuals was used. The desired amount of cyclosporin was added to whole blood at $37^{\circ} \mathrm{C}$ and incubated with gentle mixing for $1 \mathrm{~h}$. Isolation of plasma, the mononuclear cell fraction, and the red cell/granulocyte fraction was performed on a Ficoll gradient. Two millilitres of incubated blood was diluted $1 / 3$ with phosphate buffered saline (PBS) and the diluted blood layered carefully on to $4 \mathrm{ml}$ Ficoll-Paque (Pharmacia, Sydney); the samples were then centrifuged at $400 \mathrm{~g}$ for $35 \mathrm{~min}$. The top layer of diluted plasma was drawn off and retained for cyclosporin assay. The mononuclear cell layer was then removed, leaving the red cell pellet. Both the mononuclear layer and the red cell pellet were resuspended separately in PBS and centrifuged at $1000 \mathrm{~g}$ for $10 \mathrm{~min}$. After two further washes, the cells were lysed to recover the cyclosporin. The mononuclear cells were resuspended in 50:50 ethanol-PBS and lysed by rapid freezethawing in liquid nitrogen and hot water. After centrifugation, the supernatant was retained for cyclosporin assay. The red cells were resuspended in 50:50 distilled water-ethanol and vortexed. The lysed cells were centrifuged and the supernatant was retained for cyclosporin assay.

To evaluate the effect of the temperature at which the blood was separated, diluted blood was separated on Ficoll at either room temperature or $37^{\circ} \mathrm{C}$. To evaluate the effect of an increase in cyclosporin concentration during incubation, increasing concentrations were added to the incubation tube. Con-

Table 1 Effect of temperature of blood separation on serum cyclosporin concentration

\begin{tabular}{|c|c|c|}
\hline & \multicolumn{2}{|c|}{$\begin{array}{l}\text { Temperature at which blood } \\
\text { was separated }\end{array}$} \\
\hline & $37^{\circ} \mathrm{C}$ & $\begin{array}{l}\text { Room } \\
\text { temperature }\end{array}$ \\
\hline $\begin{array}{l}\text { Trough serum cyclosporin } \\
\text { concentration }(\mathrm{ng} / \mathrm{ml})(\mathrm{n}=12)\end{array}$ & $283 \pm 155$ & $104 \pm 96$ \\
\hline
\end{tabular}

Table 2 Effect on serum cyclosporin concentration of reheating blood to $37^{\circ} \mathrm{C}$ after initial cooling to room temperature

\begin{tabular}{lll}
\hline & $\begin{array}{l}\text { Blood reheated to } \\
37^{\circ} \mathrm{C} \text { after cooling to } \\
\text { room temperature* }\end{array}$ & $\begin{array}{l}\text { Blood separated at } \\
37^{\circ} \mathrm{C} \text { without cooling }\end{array}$ \\
\hline $\begin{array}{l}\text { Trough serum } \\
\text { cyclosporin } \\
\text { concentration } \\
(\mathrm{ng} / \mathrm{ml})(\mathrm{n}=26)\end{array}$ & $405 \pm 369$ & $401 \pm 375$ \\
\hline
\end{tabular}

${ }^{*}$ Values represent mean $\pm 1 \mathrm{SD}$. Difference is not significant.

centrations used were $0 \cdot 062,0 \cdot 125,0 \cdot 25,0 \cdot 5,1,2$ $3,4,6,7$, and $8 \mu \mathrm{g}$ cyclosporin $/ \mathrm{ml}$ blood. To evaluate the effects of the duration of incubation, the incubation period was varied: blood was incubated with cyclosporin for $30,60,90$, or 120 min before separation on Ficoll.

\section{STATISTICAL ANALYSIS}

This was performed using the two tailed Student's $t$ test.

\section{Results}

EFFECT OF TEMPERATURE AT WHICH BLOOD WAS SEPARATED

Trough serum cyclosporin concentration was significantly increased when blood from patients receiving cyclosporin was separated at $37^{\circ} \mathrm{C}$ compared with separation at room temperature (Table 1). When patient blood was reheated to $37^{\circ} \mathrm{C}$ before serum separation, after it had initially been allowed to cool to room temperature, the cyclosporin serum concentration was the same as that obtained in parallel samples that were separated at $37^{\circ} \mathrm{C}$ without cooling (Table 2). These findings were further investigated using blood from normal subjects incubated with cyclosporin in vitro (Fig. 1). The proportion of cyclosporin in plasma was lower, and the proportion of cyclosporin in red cells higher, at room temperature compared with $37^{\circ} \mathrm{C}$. Thus, partitioning of cyclosporin between plasma and red cells was temperature dependent, and it appeared that some cyclosporin was taken up from the serum into red cells at room temperature.

EFFECT OF DELAYING BLOOD SEPARATION With increasing delay in separation of patient blood after venesection there was a gradual increase in the cyclosporin serum concentration, regardless of whether the blood was separated at room temperature or at $37^{\circ} \mathrm{C}$ (Fig. 2). 


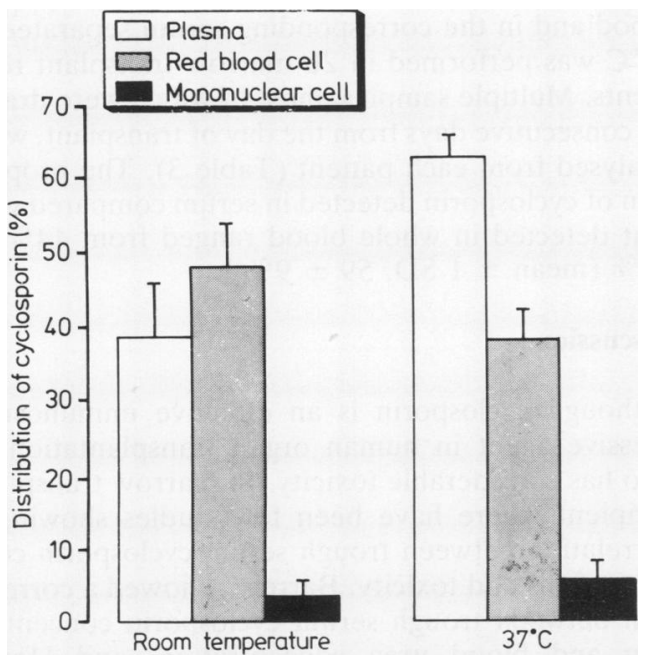

Fig. 1 Effect of temperature at which blood was separated on distribution of cyclosporin in blood components. Blood from normal subjects incubated with cyclosporin in vitro was used $(n=11)$. Values represent mean $\pm 1 S D$. The difference between the two temperatures was significant for each component $(p<0.001)$.

\section{SATURABILITY OF BLOOD COMPONENTS WITH CYCLOSPORIN}

The saturability of the three blood components (plasma, red cells, and mononuclear cells) is shown in Fig. 3. Red blood cells showed an apparent linear uptake up to an incubation concentration of $4 \mu \mathrm{g} /$ $\mathrm{ml}$, after which their uptake appeared to be satur-

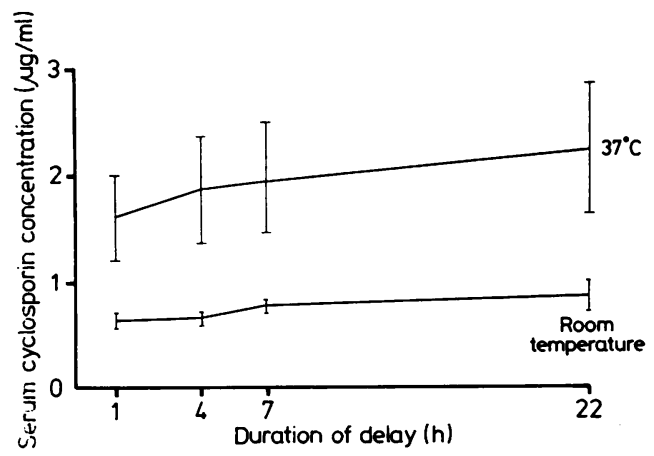

Fig. 2 Effect on serum cyclosporin concentration of delay in separation of blood (at either room temperature or $37^{\circ} \mathrm{C}$ ). Blood from patients receiving cyclosporin was used $(n=5)$. $V$ alues represent mean $\pm 1 S D$. Differences between $1 \mathrm{~h}$ and $7 h$ values and $1 h$ and $22 h$ values were significant $(p<$ 0.05 for room temperature values and $p<0.1$ for $37^{\circ} \mathrm{C}$ values).

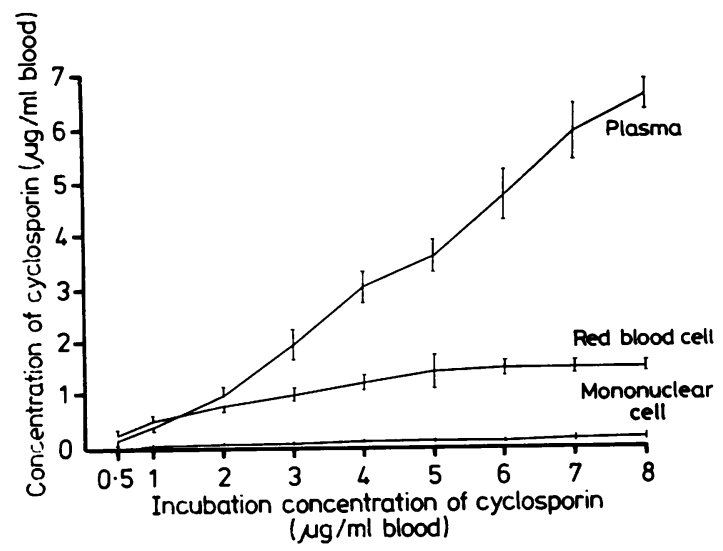

Fig. 3 Effect on concentration of cyclosporin in blood components of increasing concentrations of cyclosporin during incubation. Blood from normal subjects incubated with cyclosporin in vitro was used $(n=4)$. Values represent mean $\pm 1 S D$.

able. Both the plasma and the mononuclear cell components showed an apparent linear uptake up to $7 \mu \mathrm{g} / \mathrm{ml}$. Plasma cyclosporin concentration increased more rapidly than red cell cyclosporin concentration with increasing concentrations of cyclosporin during incubation.

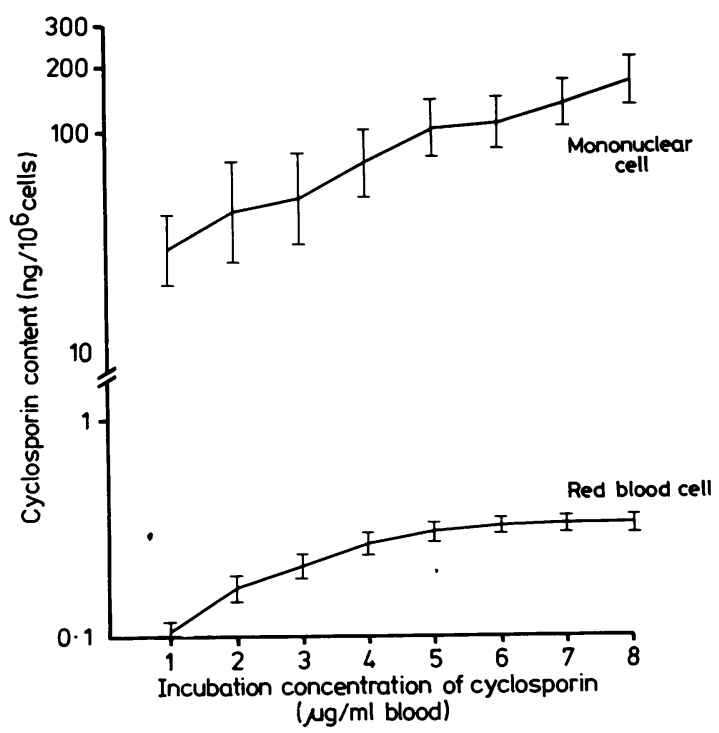

Fig. 4 Cyclosporin content of mononuclear cells and erythrocytes at increasing incubation concentrations of cyclosporin. Blood from normal subjects incubated with cyclosporin in vitro was used $(n=4)$. Values represent mean $\pm 1 S D$. 


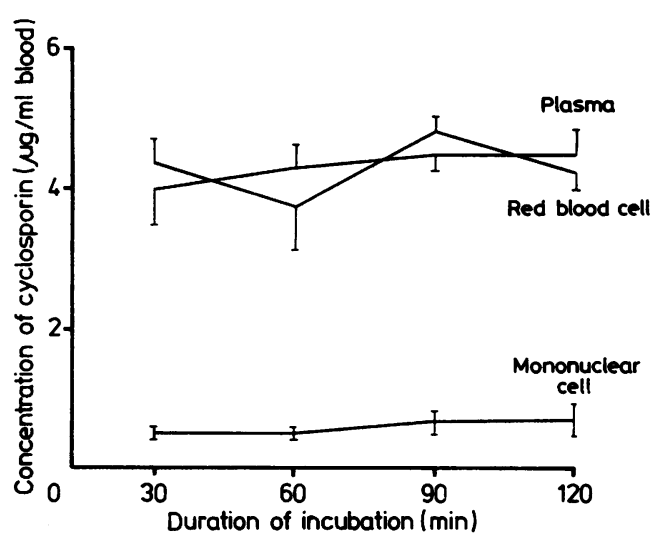

Fig. 5 Effect on cyclosporin content of blood components of increasing duration of incubation of blood with cyclosporin. Blood from normal subjects was used $(n=3)$. Values represent mean $\pm 1 S D$. Differences for different durations of incubation not significant.

CELLULAR CYCLOSPORIN CONTENT

Mononuclear cells had a cyclosporin content roughly 1000 times greater than that of erythrocytes at all concentrations of cyclosporin (Fig. 4).

EFFECT OF DURATION OF INCUBATION

There was no change in the distribution of cyclosporin between blood components when cyclosporin and blood were incubated for increasing periods of time (30-120 min) (Fig. 5). A distribution equilibrium had thus been reached within 30 min of incubation.

WHOLE BLOOD CYCLOSPORIN CONCENTRATION Estimation of cyclosporin concentration in whole blood and in the corresponding serum separated at $37^{\circ} \mathrm{C}$ was performed in 20 marrow transplant recipients. Multiple samples, most of which were drawn on consecutive days from the day of transplant, were analysed from each patient (Table 3 ). The proportion of cyclosporin detected in serum compared with that detected in whole blood ranged from $44 \%$ to $72 \%$ (mean $\pm 1 \mathrm{SD}, 59 \pm 9 \%$ ).

\section{Discussion}

Although cyclosporin is an effective immunosuppressive agent in human organ transplantation, it also has considerable toxicity. In marrow transplant recipients there have been few studies showing a correlation between trough serum cyclosporin concentrations and toxicity. Barrett ${ }^{16}$ showed a correlation between trough serum cyclosporin concentration and blood urea concentration, and Hows ${ }^{8}$ showed a correlation between trough serum cyclosporin concentration and serum creatinine values. In the latter study, however, patients with other causes of nephrotoxicity or potential nephrotoxicity (such as aminoglycoside antibiotic treatment) were included in the analysis and make interpretation of the data difficult. No studies have yet been reported

correlating serum cyclosporin values and efficacy in preventing graft versus host disease. Difficulties ino the techniques for measuring cyclosporin concentration in human serum or blood may be a reason for the lack of such studies. Lemaire ${ }^{17}$ and Hows ${ }^{18}$ have previously shown that the concentration of cyclosporin in human serum is increased roughly twofold if the blood is separated at $37^{\circ} \mathrm{C}$ rather than at room temperature before analysis. We have confirmed

Table 3 Cyclosporin content of serum separated at $37^{\circ} \mathrm{C}$ and of whole blood

\begin{tabular}{lllll}
\hline Patient no & No of samples & $\begin{array}{l}\text { Serum cyclosporin concentration } \\
(\mathrm{ng} / \mathrm{ml})\end{array}$ & $\begin{array}{l}\text { Whole blood cyclosporin } \\
\text { concentration }(\mathrm{ng} / \mathrm{ml})\end{array}$ & $\begin{array}{l}\text { Serum: whole blood cyclosporin } \\
\text { concentration ratio }\end{array}$ \\
\hline 81 & 8 & $962 \pm 506$ & $1412 \pm 783$ & $0 \cdot 68$ \\
84 & 12 & $183 \pm 131$ & $337 \pm 220$ & $0 \cdot 61$ \\
85 & 13 & $347 \pm 140$ & $606 \pm 270$ & $0 \cdot 57$ \\
95 & 12 & $592 \pm 425$ & $867 \pm 494$ & $0 \cdot 68$ \\
97 & 9 & $345 \pm 201$ & $567 \pm 192$ & $0 \cdot 61$ \\
100 & 7 & $172 \pm 259$ & $334 \pm 410$ & $0 \cdot 51$ \\
101 & 19 & $220 \pm 202$ & $444 \pm 470$ & $0 \cdot 50$ \\
102 & 19 & $162 \pm 102$ & $369 \pm 199$ & $0 \cdot 44$ \\
105 & 29 & $307 \pm 145$ & $609 \pm 172$ & $0 \cdot 50$ \\
107 & 41 & $284 \pm 195$ & $564 \pm 287$ & $0 \cdot 50$ \\
108 & 42 & $168 \pm 129$ & $339 \pm 181$ & $0 \cdot 50$ \\
109 & 31 & $215 \pm 170$ & $331 \pm 211$ & $0 \cdot 65$ \\
110 & 40 & $263 \pm 147$ & $445 \pm 135$ & $0 \cdot 59$ \\
111 & 66 & $297 \pm 261$ & $546 \pm 273$ & $0 \cdot 67$ \\
112 & 32 & $308 \pm 161$ & $535 \pm 244$ & $0 \cdot 58$ \\
113 & 29 & $385 \pm 396$ & $665 \pm 329$ & $0 \cdot 72$ \\
114 & 41 & $461 \pm 306$ & $500 \pm 260$ & $0 \cdot 69$ \\
115 & 21 & $284 \pm 242$ & $622 \pm 248$ & $0 \cdot 59$ \\
116 & 24 & $436 \pm 269$ & $429 \pm 185$ & $0 \cdot 70$ \\
117 & 14 & $207 \pm 121$ & $548 \pm 245$ & $0 \cdot 48$ \\
Mean & & & & $0 \cdot 59 \pm 0 \cdot 09$ \\
\hline
\end{tabular}

Values represent mean $\pm 1 \mathrm{SD}$. 
this in our study and have shown that this is due to uptake of cyclosporin by red cells at room temperature. We have also shown that increasing time before separation of the blood results in an increased serum cyclosporin concentration, probably due to release of cyclosporin from haemolysed red cells during the delay. ${ }^{19}$ In contrast to previous reported practice, ${ }^{19}$ however, we would recommend either that human blood be separated at $37^{\circ} \mathrm{C}$ without delay after venepuncture (rather than storing it for 2-3 h at room temperature) before separation and measurement of the serum cyclosporin concentration, or that whole blood cyclosporin concentration be measured. Separation at $37^{\circ} \mathrm{C}$ without delay minimises the uptake of cyclosporin by red cells, thus allowing a closer approximation to in vivo serum values. Such a policy would at least lessen confusion caused by two factors - the temperature dependence of serum cyclosporin concentration and the increased cyclosporin concentration due to delay in separation. If such practice is not possible, similar results can be obtained by rewarming the whole blood sample to $37^{\circ} \mathrm{C}$ before separation. Once separated, the serum can be stored at $-20^{\circ} \mathrm{C}$ with impunity for several months until the time of assay. ${ }^{14}$ The measurement of whole blood cyclosporin concentrations would avoid all these difficulties, but, again, no correlation between whole blood concentrations, toxicity, and efficacy is available.

In vitro studies showed that the distribution of cyclosporin between the three major components of the blood (plasma, erythrocytes, and mononuclear cells) depends on the temperature at which the blood was separated, the concentration of cyclosporin present during the incubation, but not on the duration of incubation. Of the three components, only the erythrocytes appeared saturable in the concentration range tested and only then at a concentration higher than would normally occur in vivo. A mononuclear cell contained much more cyclosporin than an erythrocyte. Work is in progress to determine the cyclosporin content of the $T$ cell, $T$ cell subsets, and non- $T$ cell components of mononuclear cells in order to determine if any of these parameters are useful for clinical monitoring.

This work was supported by grants from the National Health and Medical Research Council of Australia and the New South Wales State Cancer Council.

We thank Deirdre Nix for typing the manuscript and the Audiovisual Department of St Vincent's Hospital for help in the preparation of the illustrations.

\section{References}

' Andrus L, Lafferty KJ. Inhibition of T-cell activity by cyclosporin A. Scand J Immunol 1982;15:449-58.

${ }^{2}$ Bunjes D, Hardt C, Rollinghof M, Wagner H. Cyclosporin A mediates immunosuppression of primary cytotoxic $T$ responses by impairing the release of Interleukin I and interleukin II. Eur J Immunol 1981;11:657-61.

${ }^{3}$ Cyclosporin $\mathrm{A}$ as sole immunosuppressive agent in recipients receiving allografts from cadaver donors. Preliminary results of a European multicentre trial. Lancet 1982;ii:57-60.

${ }^{4}$ Reitz BA, Wallwork JL, Hunt SA, et al. Heart-lung transplantation; successful therapy for patients with pulmonary vascular disease. $N$ Engl J Med 1982;306:557-64.

5 Hows JM, Palmer S, Gordon-Smith EC. Use of cyclosporin A in allogeneic bone marrow transplantation for severe aplastic anaemia. Transplantation 1982;33:382-6.

- Deeg HJ, Storb R, Thomas ED, et al. Marrow transplantation for acute non lymphoblastic leukaemia in first remission. Preliminary results of a randomised trial comparing cyclosporine and methotrexate for prophylaxis of graft-versus-host disease. Transplant Proc 1983;15:1385-8.

' Atkinson K, Biggs JC, Hayes J. et al. Cyclosporin A-associated nephrotoxicity in the first 100 days after allogeneic bone marrow transplantation; 3 distinct syndromes. $\mathrm{Br} \mathrm{J}$ Haematol 1983:54:59-67.

${ }^{8}$ Hows JM, Chipping PM, Fairhead S, Smith J, Baughan A, Gordon-Smith EC. Nephrotoxicity in bone marrow transplant recipients treated with cyclosporin A. $\mathrm{Br} J$ Haematol 1983;54:69-78.

9 Shulman H, Striker G, Deeg HJ, Kennedy M, Storb R, Thomas ED. Nephrotoxicity of cyclosporin $A$ after allogeneic marrow transplantation. Glomerular thromboses and tubular injuries. $N$ Engl J Med 1981;305:1392-5.

${ }^{10}$ Atkinson K, Biggs J, Dodds A, Concannon A. Cyclosporineassociated hepatotoxicity after allogeneic marrow transplantation in man; differentiation from other causes of post transplant liver disease. Transplant Proc 1983;15:2761-7.

"Klintmalm GBG, Iwatsuki S, Starzl TE. Cyclosporin A hepatotoxicity in 66 renal allograft recipients. Transplantation $1981 ; 32: 488-9$.

12 Atkinson K, Biggs J, Darveniza P, Boland J, Concannon A, Dodds A. Cyclosporine-associated central nervous system toxicity after allogeneic bone marrow transplantation. Transplantation (in press)

${ }^{13}$ Biggs J, Atkinson K, Concannon A, et al. Bone marrow transplantation in 33 patients with malignant blood diseases and severe aplastic anaemia. Med J Aust 1983;2:120-5.

${ }_{14}$ Donatsch P, Abisch E, Homberger M, Traber R, Trapp M, Voges $R$. A radioimmunoassay to measure cyclosporin $A$ in plasma serum samples. J Immunoassay 1981;2:19-23.

is Atkinson K, Biggs JC, Britton K, et al. Oral administration of cyclosporin $\mathrm{A}$ for recipients of allogeneic marrow transplants; implications of clinical gut dysfunction. $\mathrm{Br} \mathrm{J}$ Haematol 1984;56:223-31

${ }^{10}$ Barrett AJ, Kendra JR, Lucas CF, et al. Cyclosporin A as prophylaxis against graft-versus-host disease in 36 patients. $\mathrm{Br}$ Med J 1982; 285: 162-6.

${ }^{17}$ Lemaire M, Niederberger W, Nussbaumer K. Factors influencing the distribution between blood cells and plasma. Consequence for the monitoring of plasma concentrations. Sandoz document $1982 ; 303$

${ }^{18}$ Hows JM, Smith JM. In vitro stability of cyclosporin A. J Clin Pathol 1983;36:720-1

${ }^{14}$ Smith JM, Hows JM, Gordon-Smith EC. Stability of cyclosporin A in human serum. $J$ Clin Pathol 1983;36:41-3.

Requests for reprints to: Dr K Atkinson, Department of Haematology, St Vincent's Hospital, Sydney, New South Wales 2010, Australia. 